\title{
Sulfuric acid and hot water treatments enhance ex vitro and in vitro germination of Hibiscus seed
}

\author{
Hamidou F. Sakhanokho
}

USDA-ARS, Thad Cochran Southern Horticultural Laboratory, P. O. Box 287, 810 High Way 26 West, Poplarville, MS 39470. E-mail: Hamidou.Sakhanokho@ars.usda.gov.

Accepted 24 August, 2009

\begin{abstract}
Seeds of Hibiscus dasycalyx S. F. Blake and Shiller, a federally listed candidate endangered species and native to North America and two variants of Hibiscus acetosella Welw. ex. Hiern were scarified using sulfuric acid and hot water. The effects of the scarification methods on in vitro and ex vitro germination in both species were evaluated. Sulfuric acid scarification was very effective for in vitro and ex vitro germination of both forms of $H$. acetosella and $H$. dasycalyx seeds by dramatically increasing germination rate and decreasing germination time. Acid scarification of $\boldsymbol{H}$. acetosella seeds for 10,15 , or 20 min resulted in close to $90 \%$ germination within a week. Germination rates of about $70 \%$ (ex vitro) and $80 \%$ (in vitro) were obtained in $\boldsymbol{H}$. dasycalyx seeds treated with sulfuric acid. Germination rates of $54 \%$ (ex vitro) and $95 \%$ (in vitro) were achieved when $\boldsymbol{H}$. dasycalyx seeds were treated with hot water for $5 \mathrm{~min}$, but exposing the seeds for 10, 15, or 20 min produced poor results in $H$. acetosella and $H$. dasycalyx as hot water scarification appeared to result in severe injury or death of the embryos. The protocols described here constitute rapid, reliable and simple methods to germinate $H$. acetosella and $H$. dasycalyx seeds in vitro and ex vitro. These results can be valuable in commercial productions or research projects. In addition, the in vitro germination of $\boldsymbol{H}$. dasycalyx can offer a valuable tool in conservation efforts for this threatened species.
\end{abstract}

Key word: Hibiscus dasycaly, Hibiscus acetosella, seed scarification, in vitro seed germination, ex vitro seed germination.

\section{INTRODUCTION}

The genus Hibiscus consists of over 300 species (Akpan, 2000) which are found in tropical, sub-tropical and temperate regions. The genus contains annuals, herbaceous perennials, shrubs and small trees. Some species are useful as sources of food and medicine (Wilson and Menzel, 1964); others are economically important as ornamentals or as bast fibers, particularly in tropical and sub-tropical regions. Among these species are $H$. acetosella Welw. ex. Hiern and $H$. dasycalyx S. F. Blake and Shiller. $H$. acetosella is native to Africa (USDA-ARSGRIN, 2006) and has two variants, a green- and red-leaf form. The red-leaf form, often referred to as 'false roselle' or 'red leaf hibiscus', is an edible tropical shrub also grown as an annual ornamental for the attractiveness of its deep burgundy red, maple-like leaves. $H$. dasycalyx, also known as the Neches River rose mallow is a federally (USA) listed candidate endangered species that is native to North America (Creech et al., 1999). Currently, it can be found only in three wetlands in Eastern Texas as it is threatened by interspecific hybridization with $H$. laevis and $H$. moscheutos as well as loss of preferred wetland habitat along the Neches River and its tributaries (Klips, 1995; Smith and Creech, 1995; Creech et al., 1999).

Rapid and synchronized germination is necessary when there is a need to subject a uniform set of seedlings to a treatment. In addition, rapid germination is advantageous when seed is used in reclamation (Greipson, 2001). However, several factors, including variability in water absorption, seed age and vigor, can lead to poor and non-uniform germination of seeds. A seed propagation study including various collection dates and stratification periods prior to planting resulted in low germination percentages in $H$. dasycalyx (Smith et al., 1995). In conservation efforts, seed is preferred over vegetative material as a source of plant material since seed provides a wider genetic base (Pickens et al., 2003). Because in vitro culture is conducted in a highly controlled environment, it constitutes a powerful tool that has been used to 
increase seed germination percentages in hard to germinate seeds and in preservation of several rare or endangered species (Batty et al., 2001; Rasmussen et al., 1990; Willis et al., 2003; Buyun et al., 2004; Lopez et al., 2004). Both hot water and sulfuric acid scarification methods are routinely used to break dormancy and promote rapid and uniform seed germination. The objective of the present study was to establish protocols that promote rapid and uniform germination in $H$. dasycalyx and the two variants of $H$. acetosella under in vitro and ex vitro conditions.

\section{MATERIALS AND METHODS}

\section{Plant material}

The species used were $\mathrm{H}$. dasycalyx and two variants of $H$. acetosella. Mature seeds were collected from greenhouse grown plants and air dried before storage in paper bags kept at room temperature (about $22^{\circ} \mathrm{C}$ ).

\section{In vitro germination experiment}

The in vitro experiment consisted of sulfuric acid and hot water scarification treatments. Seeds of the two forms (red and green forms) of $H$. acetosella and $H$. dasycalyx were immersed in $98 \%$ sulfuric acid concentration in $125 \mathrm{ml}$ beakers each containing about $40 \mathrm{ml} \mathrm{H}_{2} \mathrm{SO}_{4}$. A batch of 50 seeds was placed in each $125 \mathrm{ml}$ beaker. To assure uniform coverage, the solution was stirred continuously during the acid treatment under a fume hood. The $\mathrm{H}_{2} \mathrm{SO}_{4}$ treatment durations were 5, 10, 15 and $20 \mathrm{~min}$. The experiment was repeated twice. Because of consistent bacterial and fungal contamination and poor germination rate with seeds of $H$. dasycalyx in vitro during the study, seeds of this species were subjected to an additional and longer treatment period of $25 \mathrm{~min}$, so the $\mathrm{H}_{2} \mathrm{SO}_{4}$ treatment durations for $H$. dasycalyx in vitro were 5, 10, 15, 20 and $25 \mathrm{~min}$. This additional duration (25 min) was also included in the ex vitro germination test for $H$. dasycalyx even though contamination was not a major problem in that case. Following acid treatment, the seeds were rinsed promptly and thoroughly for about 5 min with running tap water to remove acid residues. The controls were immersed in water with no $\mathrm{H}_{2} \mathrm{SO}_{4}$. The seeds were surface sterilized under a laminar flow hood by dipping in $100 \%$ ethanol for 3 min with gentle shaking, except for $H$. dasycalyx seeds, which were dipped in $100 \%$ ethanol for $5 \mathrm{~min}$. They were then transferred into sterilized $250 \mathrm{ml}$ beakers containing $40 \%(\mathrm{v} / \mathrm{v})$ bleach $(\mathrm{NaOCl})$ solution and one drop of Tween ${ }^{\mathrm{TM}} 20$ (Sigma Aldrich Corporation, St. Louis, MO) and shaken for $20 \mathrm{~min}$ at $110 \mathrm{rpm}$. The seeds were then rinsed with sterile distilled water and stored overnight in distilled sterile water on a shaker at $110 \mathrm{rpm}$. The next day, the seeds were rinsed again three times with distilled sterile water and transferred into $100 \mathrm{~mm} \times 15 \mathrm{~mm}$ Petri dishes (3-4 seeds per dish maximum) containing MS (Murashige and Skoog, 1962) basal medium with $20 \mathrm{~g} \mathrm{l}^{-1}$ sucrose, $0.75 \mathrm{mg} \mathrm{l}^{-1} \mathrm{MgCl}_{2}$ and $2 \mathrm{~g} \mathrm{l}^{-1}$ Gelrite (Sigma Aldrich Corporation, St. Louis, MO). The $\mathrm{pH}$ of the MS medium was adjusted to 5.8 before addition of the gelling agent and autoclaving for $15 \mathrm{~min}$ at $121^{\circ} \mathrm{C}$. The Petri dishes were then placed into an incubator where the temperature was maintained constant at $28^{\circ} \mathrm{C}$ with a light intensity of $100 \mu \mathrm{mol} . \mathrm{m}^{-2} \mathrm{~s}^{-1}$ and a photoperiod regime of $16 \mathrm{~h}$ light and $8 \mathrm{~h}$ dark. Petri dishes were arranged in a completely randomized design (CRD) in the incubator. Hot water scarification was accomplished by immersing seeds in $99^{\circ} \mathrm{C}$ tap water and removing them after $0,5,15,20$, or $25 \mathrm{~min}$. For the control treatments, seeds were immersed in non heated tap water and removed as described with the hot water treatments. Seeds were then sterilized and transferred onto MS medium. Seeds were checked weekly for germination for a total period of three weeks and the number of germinated seeds was counted and the result expressed in percentages.

\section{Ex vitro germination experiment}

For the ex vitro experiment, both the acid and hot water scarifications were performed as described above, except that no surface sterilization was performed after scarification. Instead, seeds were placed in moist Whatman NO 1 (Fisher Scientific, Atlanta, GA) filter paper and transferred directly into $15 \times 95 \mathrm{~mm}$ Petri dishes $(10$ seeds per dish) which were wrapped with aluminum foil and kept in laboratory drawers at room temperature (about $22^{\circ} \mathrm{C}$ ). Filter paper was moistened as needed and seeds were checked for germination weekly for a total period of 21 days. For both in vitro and ex vitro experiments, the mean weekly percentage germination and the total percentage germination after three weeks were determined. Data was subjected to the analysis of variance (ANOVA) and mean separation was done using SAS software (SAS, Inc., 2003).

\section{RESULTS AND DISCUSSION}

\section{Effect of $\mathrm{H}_{2} \mathrm{SO}_{4}$ on ex vitro seed germination}

$\mathrm{H}_{2} \mathrm{SO}_{4}$ scarification was very effective for both forms of $H$. acetosella and $H$. dasycalyx by substantially enhancing the germination rate and also reducing the germination period (Tables 1, 2 and 3). For the green form of $H$. acetosella, there were significant $(P=0.05)$ germination differences among scarification durations in week 1, 2, 3 or in total percentage germination (Table 1). For this genotype in week 1 , significantly germination perecentages (up to $92 \%$ compared to only $6 \%$ ) were obtained when seeds were scarified with $98 \% \mathrm{H}_{2} \mathrm{SO}_{4}$ for 10,15 , or $20 \mathrm{~min}$. Not only did the acid scarification improved seed germination but it also shortened the germination time as germinated seeds could be observed after only two days. The highest total germination rate for the green form of $H$. acetosella ex vtiro was obtained when seeds were acid scarified for 20 min even though this result was not significantly different $(P=0.05)$ from those obtained with the 5,10 , or 15 min treatments (Table 1). For the red-leaf hibiscus, the results obtained ex vitro with $\mathrm{H}_{2} \mathrm{SO}_{4}$ scarification were similar to those obtained with the green $\mathrm{H}$. acetosella genotype (Tables 1 and 2). As in the case of the green genotype, most of the red-leaf hibiscus seeds germinated within one week when they were acid scarified for $5,10,15$, or $20 \mathrm{~min}$ (Table 2). The highest total germination rate (98\%) after three weeks was obtained when seeds were acid treated for 10 or $20 \mathrm{~min}$ even though these results were not significantly different $(P=0.05)$ from those obtained with the acid treated seeds for 5 or 15 min.

For $H$. dasycalyx, there were significant differences $(P$ $=0.05$ ) among the $\mathrm{H}_{2} \mathrm{SO}_{4}$ treatment durations in week 1 , 2 , 3, as well as for the total percentage germination (Table 3). In week 1, the highest percentage germination 
Table 1. Effect of sulfuric acid and hot water scarification on in vitro and ex vitro seed germination of Hibiscus acetosella (green variant).

\begin{tabular}{|c|c|c|c|c|c|}
\hline \multirow{2}{*}{$\begin{array}{c}\text { Scarification } \\
\text { type }\end{array}$} & \multirow{2}{*}{$\begin{array}{c}\text { Duration } \\
\text { (min) }\end{array}$} & \multicolumn{4}{|c|}{ Germination (\%) } \\
\hline & & Week 1 & Week 2 & Week 3 & Total \\
\hline \multicolumn{6}{|l|}{$\mathrm{H}_{2} \mathrm{SO}_{4}$ ex vitro } \\
\hline & 0 & $6 c$ & $0 \mathrm{~b}$ & $0 b$ & $6 b$ \\
\hline & 5 & $72 b$ & $12 a$ & $2 a$ & $86 a$ \\
\hline & 10 & $86 a$ & $2 b$ & $0 b$ & $88 a$ \\
\hline & 15 & $92 a$ & $0 \mathrm{~b}$ & $0 \mathrm{~b}$ & $92 a$ \\
\hline & 20 & $92 a$ & $2 b$ & $2 a$ & $96 a$ \\
\hline \multicolumn{6}{|l|}{$\mathrm{H}_{2} \mathrm{SO}_{4}$ in vitro } \\
\hline & 0 & $18 \mathrm{c}$ & $2 b$ & $5 a$ & $25 b$ \\
\hline & 5 & $72 b$ & $16 a$ & $4 a$ & $92 a$ \\
\hline & 10 & $88 a$ & $2 b$ & $0 b$ & $90 a$ \\
\hline & 15 & $86 a$ & $0 b$ & $6 a$ & $92 a$ \\
\hline & 20 & $88 a$ & $0 \mathrm{~b}$ & $\mathrm{Ob}$ & $88 a$ \\
\hline \multicolumn{6}{|c|}{ Hot water ex vitro } \\
\hline & 0 & $15 a$ & $0 \mathrm{~b}$ & $0 \mathrm{a}$ & $15 a$ \\
\hline & 5 & $\mathrm{Ob}$ & $6 a$ & $0 \mathrm{a}$ & $6 b$ \\
\hline & 15 & $0 b$ & $0 b$ & $0 \mathrm{a}$ & $0 c$ \\
\hline & 20 & $0 \mathrm{~b}$ & $0 \mathrm{~b}$ & $0 \mathrm{a}$ & $0 \mathrm{c}$ \\
\hline \multicolumn{6}{|c|}{ Hot water in vitro } \\
\hline & 0 & $18 \mathrm{a}$ & $5 a$ & $4 a$ & $27 a$ \\
\hline & 5 & $2 b$ & $0 b$ & $0 b$ & $2 b$ \\
\hline & 15 & $0 b$ & $0 b$ & $0 b$ & $\mathrm{Ob}$ \\
\hline & 20 & $0 \mathrm{~b}$ & $\mathrm{Ob}$ & $\mathrm{Ob}$ & $\mathrm{Ob}$ \\
\hline
\end{tabular}

Means with the same letter belonging to the same scarification type and within the same week column are not significantly different at $P=0.05$ according to Tukey's test.

was achieved when $H$. dasycalyx seeds were acid scarified for 20 min even though this germination percentage was not significantly different $(P=0.05)$ than those obtained with 15 or 25 min (Table 3). However, this result (58\% germination) was a significant improvement over the control that produced only $6 \%$ germination.

\section{Effect of hot water on ex vitro seed germination}

Hot water treatment was ineffective for both variants of $H$. acetosella as the highest germination rates were only 6 and $5 \%$ for the green and red genotypes, respectively (Tables 1 and 2). No seed germination was obtained for any of the two forms of $\mathrm{H}$. acetosella treated with hot water for a duration that lasted over $5 \mathrm{~min}$, probably because the embryos were severely injured or killed. Thus, hot water treatment is not a suitable scarification method for $H$. acetosella. On the other hand, $54 \%$ of $H$. dasycalyx seeds treated with hot water for $5 \mathrm{~min}$ germinated within after three weeks (Table 3 ), but as this was the case with the two $H$. acetosella genotypes, no $H$. dasycalyx seeds treated with hot water for more than 5 min germinated, even after three weeks (Table 3).

\section{Effect of $\mathrm{H}_{2} \mathrm{SO}_{4}$ on in vitro germination}

There were significant differences $(P=0.05)$ among acid treated seeds for the various scarification durations for all three hibiscus genotypes (Tables 1,2 and 3). For the green variant of $H$. acetosella, the best results were obtained when seeds were acid treated for 10,15 , or 20 min (Table 1). A total of 25 percent of the non scarified $H$. acetosella (green form) seeds germinated over a period of 21 days compared to $92 \%$ germination when seeds were treated with $\mathrm{H}_{2} \mathrm{SO}_{4}$ for 5 or 15 min (Table 1). The effect of acid scarification on seed germination was similar in the red form of $H$. acetosella (Table 2). Only $27 \%$ of the control seeds germinated during the 21 day period compared to the $98 \%$ germination achieved with $\mathrm{H}_{2} \mathrm{SO}_{4}$ treated seeds for 15 or $20 \mathrm{~min}$ and high percentages of seeds germinated in one week after acid treatment for 10 , 15 , or 20 min (Table 2 ).

For $H$. dasycalyx, only $4 \%$ of the control seeds germinated in vitro after three weeks (Table 3). Germination rate was also low when seeds were acid treated for 5,10 , or $15 \mathrm{~min}$. In addition, seeds that germinated after acid treatment for these initial durations were often lost due to bacterial and or fungal contamination. Consequently, seeds 
Table 2. Effect of sulfuric acid and hot water scarification on in vitro and ex vitro seed germination of Hibiscus acetosella (red variant).

\begin{tabular}{|c|c|c|c|c|c|}
\hline \multirow{2}{*}{$\begin{array}{c}\text { Scarification } \\
\text { type }\end{array}$} & \multirow{2}{*}{$\begin{array}{l}\text { Duration } \\
\text { (min) }\end{array}$} & \multicolumn{4}{|c|}{ Germination (\%) } \\
\hline & & Week 1 & Week 2 & Week 3 & Total \\
\hline \multicolumn{6}{|l|}{$\mathrm{H}_{2} \mathrm{SO}_{4}$ ex vitro } \\
\hline & 0 & $6 \mathrm{c}$ & $8 \mathrm{c}$ & $0 a b$ & $14 b$ \\
\hline & 5 & $72 b$ & $15 a$ & $2 a$ & $89 a$ \\
\hline & 10 & $86 a$ & $10 a b$ & $2 a$ & $98 a$ \\
\hline & 15 & $94 a$ & $2 d$ & $1 a b$ & $97 a$ \\
\hline & 20 & $93 a$ & $3 d$ & $2 a$ & $98 a$ \\
\hline \multicolumn{6}{|l|}{$\mathrm{H}_{2} \mathrm{SO}_{4}$ in vitro } \\
\hline & 0 & $19 \mathrm{c}$ & $4 \mathrm{~b}$ & $4 \mathrm{~b}$ & $27 \mathrm{~b}$ \\
\hline & 5 & $70 b$ & $20 a$ & $3 b$ & $93 a$ \\
\hline & 10 & $89 a$ & $5 b$ & $0 \mathrm{c}$ & $94 a$ \\
\hline & 15 & $87 a$ & $3 b c$ & $8 a$ & $98 a$ \\
\hline & 20 & $93 a$ & $2 \mathrm{bc}$ & $3 b$ & $98 a$ \\
\hline \multicolumn{6}{|c|}{ Hot water ex vitro } \\
\hline & 0 & $17 a$ & $3 a$ & $0 \mathrm{a}$ & $21 a$ \\
\hline & 5 & $\mathrm{Ob}$ & $5 a$ & $0 \mathrm{a}$ & $5 b$ \\
\hline & 15 & $\mathrm{Ob}$ & $0 b$ & $0 a$ & $0 c$ \\
\hline & 20 & $\mathrm{Ob}$ & $0 b$ & $0 a$ & $0 \mathrm{c}$ \\
\hline \multicolumn{6}{|c|}{ Hot water in vitro } \\
\hline & 0 & $21 a$ & $3 a$ & $2 a$ & $26 a$ \\
\hline & 5 & $2 b$ & $\mathrm{Ob}$ & $\mathrm{Ob}$ & $2 b$ \\
\hline & 15 & $\mathrm{Ob}$ & $\mathrm{Ob}$ & $\mathrm{Ob}$ & $\mathrm{Ob}$ \\
\hline & 20 & $0 b$ & $\mathrm{Ob}$ & $\mathrm{Ob}$ & $\mathrm{Ob}$ \\
\hline
\end{tabular}

Means with the same letter belonging to the same scarification type and within the same week column are not significantly different at $P=0.05$ according to Tukey's test.

were scarified for a longer time period ( $25 \mathrm{~min}$ ). Surface sterilization protocol was also modified as follows. Seeds were placed in $100 \%$ ethanol for 5 min (instead of 3) and the bleach concentration was increased from 40 to $50 \%$. The rest of the procedure remained unchanged. $H$. dasycalyx has calyx, bracteoles and mature seeds that are densely pubescent, creating a favorable environment for bacteria and fungi. Bacterial or fungal contamination could be reduced by removing the seed coats and plating fewer seeds in each Petri dish. Seed coat removal was found to improve germination rate and reduce contamination problem in cotton (Sakhanokho et al., 2001). However, the drawback of this procedure is that it is more time and supply consuming. The total germination percentage significantly $(P=0.05)$ improved when $H$. dasycalyx seeds were acid treated for 20 or $25 \mathrm{~min}$, which produced 80 and $84 \%$ germination, respectively compared to only $4 \%$ germination for the control (Table 3 ).

\section{Effect of hot water on in vitro seed germination}

As this was the case in the ex vitro test, hot water treatment was ineffective for both variants of $H$. acetosella as the highest germination rate after hot water treatment was only $2 \%$ after a 5 min treatment for both the green and red genotypes (Tables 1 and 2). Similar to the ex vitro seed germination test, no seed germination was obtained for any of the two forms of $H$. acetosella treated with hot water for a duration that lasted over $5 \mathrm{~min}$. On the other hand, there was a marked improved germination rate in $H$. dasycalyx as $95 \%$ of the seeds treated with hot water for 5 min germinated after three weeks and noticeably, $74 \%$ of the seeds germinated in the first week (Table 3). However, as this was the case with the ex vitro test, no $H$. dasycalyx seeds treated with hot water for more than $5 \mathrm{~min}$ germinated in vitro, even after three weeks (Table 3).

\section{Conclusion}

In summary, sulfuric acid scarification was effective for $\mathrm{H}$. dasycalyx and $H$. acetosella germination under both in vitro and ex vitro conditions. However, hot water scarification was only effective for $H$. dasycalyx seed germination in vitro and ex vitro when seeds were treated for no longer than $5 \mathrm{~min}$. It was ineffective for $H$. acetosella 
Table 3. Effect of sulfuric acid and hot water scarification on in vitro and ex vitro seed germination of Hibiscus dasycalyx.

\begin{tabular}{|c|c|c|c|c|c|}
\hline \multirow{2}{*}{$\begin{array}{c}\text { Scarification } \\
\text { type }\end{array}$} & \multirow{2}{*}{$\begin{array}{c}\text { Duration } \\
\text { (min) }\end{array}$} & \multicolumn{4}{|c|}{ Germination (\%) } \\
\hline & & Week 1 & Week 2 & Week 3 & Total \\
\hline \multicolumn{6}{|l|}{$\mathrm{H}_{2} \mathrm{SO}_{4}$ ex vitro } \\
\hline & 0 & $6 c$ & $3 c$ & $6 c$ & $15 b$ \\
\hline & 5 & $8 c$ & $4 c$ & $7 c$ & $19 b$ \\
\hline & 10 & $14 b$ & $48 a$ & $4 a$ & $66 a$ \\
\hline & 15 & $54 a$ & $10 \mathrm{~b}$ & $0 c$ & $64 a$ \\
\hline & 20 & $58 a$ & $9 b$ & $3 b$ & $70 a$ \\
\hline & 25 & $57 a$ & $11 \mathrm{~b}$ & $2 b$ & $70 a$ \\
\hline \multicolumn{6}{|l|}{$\mathrm{H}_{2} \mathrm{SO}_{4}$ in vitro } \\
\hline & 0 & $0 c$ & $2 c$ & $2 b$ & $4 c$ \\
\hline & 5 & $0 c$ & $0 c$ & $0 c$ & $0 c$ \\
\hline & 10 & $0 c$ & $0 c$ & $0 c$ & oc \\
\hline & 15 & $16 b$ & $14 b$ & $4 a$ & $34 b$ \\
\hline & 20 & $54 a$ & $26 \underline{a}$ & $0 c$ & $80 a$ \\
\hline & 25 & $56 a$ & $28 \mathrm{a}$ & $0 \mathrm{c}$ & $84 a$ \\
\hline \multicolumn{6}{|c|}{ Hot water ex vitro } \\
\hline & 0 & $9 a$ & $8 b$ & $6 b$ & $23 b$ \\
\hline & 5 & $0 b$ & $36 a$ & $18 \mathrm{a}$ & $54 a$ \\
\hline & 15 & $0 b$ & oc & $0 c$ & oc \\
\hline & 20 & $0 \mathrm{~b}$ & $0 \mathrm{c}$ & $0 \mathrm{c}$ & $0 \mathrm{c}$ \\
\hline \multicolumn{6}{|c|}{ Hot water in vitro } \\
\hline & 0 & $11 b$ & $5 b$ & $4 a$ & $20 \mathrm{~b}$ \\
\hline & 5 & $74 a$ & $18 \mathrm{a}$ & $3 a$ & $95 a$ \\
\hline & 15 & $0 c$ & $0 c$ & $0 b$ & oc \\
\hline & 20 & $0 c$ & $0 \mathrm{c}$ & $0 \mathrm{~b}$ & $0 c$ \\
\hline
\end{tabular}

Means with the same letter belonging to the same scarification type and within the same week column are not significantly different at $P=0.05$ according to Tukey's test.

seed germination in vitro and ex vitro. The protocols described here constitute rapid, reliable and simple methods to germinate $H$. acetosella and $H$. dasycalyx seeds in vitro and ex vitro. They can be very valuable in commercial productions or research projects involving these species since poor and erratic seed germination can be a hindrance in commercial nursery systems as well as in research settings where there is a need to subject a uniform group of seedlings to a treatment. In addition, the in vitro germination of $H$. dasycalyx can offer a valuable tool in conservation efforts for this threatened species.

\section{REFERENCES}

Akpan GA (2000). Cytogenetic characteristics and breeding system in six Hibiscus species. Theor. Appl. Genet. 100: 315-318.

Batty AL, Dixon KW, Brundrett M, Sivasithamparam K (2001). Constraints to symbiotic germination of terrestrial orchid seed in a Mediterranean bushland. New Phytol. 152: 511-520.

Buyun L, Lavrentyeva A, Kovalska L, Ivannikov R (2004). In vitro germination of seeds of some rare tropical orchids. Acta
Universitantis Latviensis, Biology, 676: 159-162.

Creech D, Parish D, Clark B (1999). Saving the Neches River rose mallow, Hibiscus dasycalyx. Native Plant Society of Texas News 17: 1-3.

Greipson $S$ (2001). Effects of stratification and $\mathrm{GA}_{3}$ on seed germination of a sand stabilising grass Leymus arenarius used in reclamation. Seed Sci. Technol. 29: 1-10.

Klips RA (1995). Genetic affinity of the rare eastern Texas endemic Hibiscus dasycalyx (Malvaceae). Am. J. Bot. 82: 1463-1472.

Murashige T, Skoog F (1962). A revised medium for rapid growth and bioassays with tobacco tissue culture. Physiol. Plant. 15:473-497.

Lopez IS, Luis JC, Armas MR, Gonzalez FV (2004). In vitro propagation of Helianthemum bystropogophyllum Svent., a rare and endangered species from Gran Canaria (Canary Islands). Bot. Macaronesica 25: 71-77.

Pickens KA, Affolter JM, Wetzstein HY (2003). Enhanced seed germination and seedling growth of Tillandsia eizii in vitro. Hort. Sci. 38: 101-104.

Rasmussen H, Anderson TF, Johanesn B (1990). Temperature sensitivity of in vitro germination and seedling development of Dactylorhiza majalis (Orchidaceae) with and without mycorrhizal fungus. Plant Cell Environ. 13: 171-177.

Sakhanokho HF, Zipf A, Rajasekaran K, Saha S, Sharma GC (2001). Induction of highly embryogenic calluses and plant regeneration in Upland and Pima cottons. Crop Sci. 41: 1235-1240.

SAS Institute (2003). SAS 9.1.3. SAS Institute, Inc., Cary, NC, USA. 
Smith E, Creech D (1995). A propagation and reintroduction strategy for the Neches River rose mallow, Hibiscus dasycalyx. HortScience 30:805-806

USDA, ARS (2006). National Genetic Resources Program. Germplasm Resources Information Network-(GRIN) [Online Database]. National Germplasm Resources Laboratory,

Wilson FD, Menzel MY (1964). Kenaf (Hibiscus cannabinus), roselle (Hibiscus sabdariffa). Econ. Bot. 18: 80-91.
Willis AJ, McKay R, Vranjic JA, Kilby MJ, Groves RH (2003). Comparative seed ecology of the endangered shrub, Pimelea spicata and a threatening weed, bridal creeper: smoke, heat and other firerelated germination cues. Ecol. Manage. Restoration 4: 55-65. 